\title{
SEMANTIC ANALYSIS OF LANGUAGE ACQUISITION IN THREE YEARS OLD CHILD
}

\author{
Tri Indah Rezeki ${ }^{\mathbf{1}}$ \\ STKIP Budidaya Binjai \\ Jl. Gaharu No. 147, Jatimakmur, Binjai Utara. \\ trindah.rizky@gmail.com \\ Rakhmat Wahyudin Sagala ${ }^{2}$ \\ Universitas Muhammadiyah Sumatera Utara \\ Medan, Indonesia \\ rakhmatwahyudin@umsu.ac.id
}

\begin{abstract}
Three years old children acquire language after their first language and it is influenced by two factors, namely physiological factors and psychological factors. Physiological factors include speech-producing organs such as mouth and brain function. Meanwhile, psychological factors include development cognitive of a child in the process of mastering his or her first language. This study was conducted to analyze the semantic analysis of language acquisition in 3 years old child. Specifically, it discussed about the errors of phonemes which were spoken by three years old child so that it can influence the meaning of the words semantically. The results obtained indicated that language acquisition of child aged 3 years old was still in the process of development language that will become perfect as them get older. There are 14 words that were not appropriate semantically. Those words were often spoken by the child. The relation between semantics and language acquisition of 3 years old child were assessed still in the development stage according to her age.
\end{abstract}

Keywords: Language Acquisition; linguistics, Semantics; language development of three years old child

\section{INTRODUCTION}

Language as a means of communication only exists in human. Human interact to one another through communication in the form of language. The communication occurs both verbally and non-verbally with writing, reading, and signs or symbols. Speaking is a complex process. Human communicate through language and require a process that develops in stages of their age. The way of human to acquire language as a way of communicating is always an interesting subject to be discussed thus giving many theories about language acquisition. It is over complex and extensive considering that there are more than a thousand languages in the world.

Rezeki and Sagala (2019) state that language is widely considered to be the most essential communication instrument to convey information. Remarkably, a feature of language meaning is not only related to the words selections, but also how the way to convey it. When the speaker cannot convey his/her message by using one language, the speaker needs to change the language to be more understood (Sagala and Rezeki, 2018). 
Language is a form of rules or symbol systems used by children to communicate and to adapt to their environment which is done to exchange ideas, thoughts, and emotions. Language can be expressed through speech by referring to symbols verbal. In addition, language can also be expressed through writing, gestural signs and music. Language can also include aspects of nonverbal communication such as gesticulation, gestural or pantomime.

The development of children's communication actually starts early, first of all from her crying. At 3 weeks, babies smile when there are external stimuli, such as person's face, the gaze, the voice and the tickle. The language acquisition process is a part which is important in the development of individual language skills. Language acquisition is a process that takes place in the brain of a child when he is acquired his first language or mother tongue (Chaer, 2003). Children can master their first language while in this process.

Every child experiences language development differently. However on basically every normal child begins to talk between the ages of twenty to twenty eight months. This happens because of the speech organs that each child has have started to develop and are programmed to acquire language. One of the vocabulary groups that is mastered by the children is the class of nouns, especially those that are familiar with where they live. In fact, the stimulation of language received by children is irregular. However, they try to understand the linguistic systems of language.

In essence language acquisition, especially three year olds have formed full sentences because they couldn't say more than one syllable yet, they could only take one word from the whole sentence for the real child (Dardjowidjojo, 2008).

The problem of this study is the acquisition of child aged 3 years old which have errors in phoneme examined from the perspective of semantic studies. The purpose of this study is to describe semantic analysis of language acquisition in 3 years old child.

The previous study has been done by Sagala (2019) about Language Acquisition of Children in Linguistic Period. This study discussed about the language acquisition of 3 and five years old children that have the stage of language development, namely the two-word speech stage, word inflection, interrogative and deny sentences and the rare and complex construction stage. The second study came from Rezeki and Sagala (2019) about the language acquisition of three and 5 years old. They found that there are factors which affect children language acquisition aged 3 years and 5 years old namely heredity such as intelligence and personality factors, social background factors such as family relationships, social status and surrounding environment.

During the acquisition of the first language, Chomsky (1965) mentions that there are two processes that happened. The processes are competence process and performance process. Competence is the process of mastery of grammar (phonology, morphology, syntax, and semantics) unconsciously. This competence is carried by every child from birth. Although it is brought from birth, competence requires coaching so that children have performance in language. Performance is the child's ability to 
use language to communicate. Performance consists of two processes, namely the process of understanding and the process of publishing sentences. The process of understanding involves the ability to observe or to perceive the sentences heard, while the publishing process involves the ability to produce their own sentences (Chaer, 2003).

Chaer (2003) adds that language contains symbols for exchanging information. Language ability can be seen or assessed. Language and speech development described as follows:

a. Receptive language (Pre-verbal period). This period is from the first crying to the first word spoken. Babies produce their usual pre-linguistic language according to who takes care of them. The language that is originally issued is cooing or sounds such as certain "vowel" sounds (such as "au" or "u"). The step of prelinguistic cooing is usually heard at 4-6 weeks of age.

b. Expressive language (verbal period). The child's ability to express meaningful words (usually at 12-18 months of age). For example, they can say "Mama" or "Papa".

Children aged 3 years begin to recognize and learn to say simple words even though their pronunciation is not yet perfect and are able to compose words and convey their communication in a sentence like adults. They are able to recognize verbs and pronouns, they can also convey their wishes in the form of sentences such as "I want to eat bread", "I want to play", and so on. Not only can convey their wishes, at this age children are also able to ask questions, protest, reject, or convey feelings.
The explanation about is part of the child's language development in 3 years old. The language of children will continue to develop according to the their age.

Halliday and Jonathan (2006) state that Linguistics refers to the scientific study of language. Linguistics involves a vast, complex and systematic study, with different core areas such as phonology, phonetics, morphology, syntax and semantics. It is also intertwined with various other disciplines and contains fields like sociolinguistics, psycholinguistics etc. This study focused on semantics that was related to phonology such as phoneme.

According to Verhaar (2008) semantics is a branch of linguistics that examines meaning. Semantics are divided into grammatical and lexical semantics. Grammatically, elements that carry the smallest grammatical meaning are morphemes like affixation. Meanwhile, the lexical aspect of the elements is lexicology. This includes a large number such as meaning and reference, denotation and connotation, extensional and intentional analysis.

\section{METHOD}

The method of this study is a descriptive qualitative research. According to Moleong (2005), descriptive qualitative research is a research based on data collected in the form of words, pictures, and not numbers. This study described semantic analysis of language acquisition in 3 years old child.

The subject of this study was a child aged 3 years old whose name is TR. The object of this study is the utterances of 3 years old child that have error phonemes and related to the meaning semantically. The data was collected by using 
observation and taking note techniques. The researcher had observed the daily language in 3 years old child. Then, the data was analyzed based on the semantic theory.

\section{RESULT AND DISCUSSION}

\section{a. Data Analysis}

In children language acquisition, the utterances of 3 years old child still have error pronunciation especially the error of their phonemes. The mastery of language of 3 years old child was still in process to be perfect semantically. This is the example of TR's utterance aged 3 years old.

\begin{tabular}{cl}
$\begin{array}{l}\text { Table 1. TR's Utterance in Sentences } \\
\text { No. }\end{array}$ & \multicolumn{1}{c}{ TR's Utterances } \\
\hline 1. & Mi, adek mau sogok gigi \\
\hline 2. & Liat itu ada kaskoa \\
\hline 3. & Kak, ayo main pasil \\
\hline 4. & Kita tadi lewat tewolongan \\
\hline 5. & Ami buat bulgel \\
\hline 6. & Adek pakai cingjet \\
\hline 7. & Ami pakai hespet \\
\hline 8. & Adek mau buat juz pakai blendel \\
\hline 9. & Adek uda Ilqo' dua \\
\hline 10. & Lagunya kita mehamani \\
\hline 11. & Adek mau punya tlek penggali \\
\hline 12. & Mi, balte mainannya abis \\
\hline 13. & Kak, kita main esternet \\
\hline 14. & Kakak menamun
\end{tabular}

The utterances were often spoken by child. Based on the data, it could be seen that there were 14 words that had error phonemes so that the meanings were not clear semantically. The analysis could be seen in table 3.2.

\section{Table 2 Data Analysis}

\begin{tabular}{ccl} 
No. & Utterance & Meaning \\
\hline 1. & Sogok gigi & Gosok gigi \\
\hline 2. & Kaskoa & Kecoa \\
\hline 3. & Pasil & Pasir \\
\hline 4. & Tewolongan & Terowongan
\end{tabular}

\begin{tabular}{ccl}
5. & Bulgel & Burger \\
\hline 6. & Cingjet & Singlet \\
\hline 7. & Hespet & Headset \\
\hline 8. & Blendel & Blender \\
\hline 9. & Ilqo' & Iqro' \\
\hline 10. & Mehamani & Memahami \\
\hline 11. & Tlek penggali & Truk penggali \\
\hline 12. & Balte & Batre \\
\hline 13. & Esternet & Internet \\
\hline 14. & Menamun & Melamun \\
\hline
\end{tabular}

The errors of phonemes of the data were analyzed semantically that could be described as follows:

1. Sogok gigi should be gosok gigi. The errors were found in the phoneme $/ \mathrm{s} / \mathrm{in} / \mathrm{so} /$ should be $/ \mathrm{go} /$ and $/ \mathrm{g} /$ in $/ \mathrm{gok} /$ should be $/ \mathrm{sok} /$ so that the meaning is wrong semantically.

2. Kaskoa should be kecoa. The errors were found in the phoneme $/ \mathrm{k} /$ in $/ \mathrm{kas} /$ should be $/ \mathrm{ke} /$ and phonemen $/ \mathrm{k} /$ in $/ \mathrm{koa} /$ should be lcoal

3. Pasil should be pasir. The error was found in the phoneme $/ l /$ should be $/ r /$.

4. Tewolongan should be terowongan. The errors were found in the phoneme $/ w /$ in $/ w o /$ should be $/ \mathrm{ro} /$ and in the phoneme $/ \mathrm{l} / \mathrm{in} / \mathrm{lo} /$ should be /wo/.

5. Bulgel should be burger. The error was found in the phoneme $/ /$ should be $/ r /$

6. Cingjet should be singlet. The errors were found in the phoneme / $/$ / in /cing/ should be /sing/and in the phoneme / $/$ / in /jet/ should be /let/.

7. Hespet should be headset (pronounced hed set). The errors were found in the phoneme /s/ in /hes/ should be /hed/ and in the phoneme /p/ in /pet/should be /set/.

8. Blendel should be blender. The error was found in the phoneme $/ l /$ in /del/ should be /der/.

9. Ilqo' should be iqro'. The errors were found in the phoneme $/ / /$ in $/ \mathrm{il} /$ should be $/ \mathrm{iq} /$ and in the phoneme $/ q /$ in $/ q o \%$ should be $/ r o \%$ 
10. Mehamani should be memahami. The errors were found in the phoneme $/ \mathrm{h} / \mathrm{in} / \mathrm{ha} /$ should be $/ \mathrm{ma} /$, in the phoneme $/ \mathrm{m} /$ in $/ \mathrm{ma} /$ should be $/ \mathrm{ha} /$ and in the phoneme $/ \mathrm{n} / \mathrm{in} / \mathrm{ni} /$ should be /mi/.

11. Tlek should be truk. The errors were found in the phoneme $/ /$ in $/ t l /$ should be $/ t r /$ and in the phoneme /e/ in /ek/ should be $/ u k /$.

12. Balte should be batre. The errors were found in the phoneme $/ / /$ in $/ \mathrm{bal} /$ should be $/ \mathrm{bat} /$ and in the phoneme $/ \mathrm{t} / \mathrm{in} / \mathrm{te} / \mathrm{should}$ be $/ \mathrm{re} /$.

13. Esternet should be internet. The errors were found in the phoneme /es/ should be /in/

14. Menamun should be melamun. The errors were found in the phoneme $/ \mathrm{n} / \mathrm{in} / \mathrm{na}$ / should be $/ l a /$.

From the data analysis, the researchers found that there were 14 words of TR's utterances that have error phonemes so that the utterances had different meanings from the semantic meanings.

\section{CONCLUSION}

Language acquisition of 3 years old child has some stages before she can pronounce the words perfectly. 14 words that were often spoken by the subject of this study have error phonemes in her utterance so that the words have different meaning semantically.

\section{REFERENCES}

Chaer, Abdul. 2003. Psikolinguistik: Kajian Teoretik. Jakarta: Rineka Cipta

Chomsky, N. 1965. Aspects of the Theory of Syntax. The Massachussets Institute of Technology. MIT Press
Dardjowidjojo, $\quad$ Soenjono. 2008. Psikolinguistik (Pengantar pemahaman bahasa manusia). Jakarta: Yayasan Obor Indonesia.

Halliday, Michael A.K. and Jonathan, Webster. 2006. On Language and Linguistics. Continuum International Publishing Group. p. vii.

Moleong, Lexy J. 2005. Metodologi Penelitian Kualitatif. Bandung: PT. Remaja Rosdakarya.

Rezeki, T. I., \& Sagala, R. W. (2019).Semantics Analysis of Slang (SAOS) in Social Media of Millennial Generation. KREDO: Jurnal Ilmiah Bahasa dan Sastra, 3(1), 36-46.

Rezeki, T. I., \& Sagala, R. W. (2019). Pemerolehan Bahasa Anak Periode Linguistik. Jurnal Artikula, 2(2), 1-7.

Sagala, R. W., \& Rezeki, T. I. (2018). Code Switching in The English Department Proposal Seminar. Budapest International and Critics in Linguistics and Education (BirLE) Journal, 1(1),1114.

Sagala, R. W. (2019). LANGUAGE ACQUISITION PADA ANAK PERIODE LINGUISTIK. Serunai: Jurnal Ilmiah Ilmu Pendidikan, 5(1), 8489.

Verhaar. J.M.W. 2008. Asas-asas Linguistik Umum. Yogyakarta: Gadjah Mada Universitiy Press. 